\title{
Bicorrelations and cross-bicorrelations as non-linearity tests and tools for exchange rate forecasting
}

Article

Accepted Version

Brooks, C. and Hinich, M. J. (2001) Bicorrelations and crossbicorrelations as non-linearity tests and tools for exchange rate forecasting. Journal of Forecasting, 20 (3). pp. 181-196. ISSN 1099-131X doi: https://doi.org/10.1002/1099-

131X(200104)20:3<181::AID-FOR781>3.0.CO;2-R Available at https://centaur.reading.ac.uk/35981/

It is advisable to refer to the publisher's version if you intend to cite from the work. See Guidance on citing.

Published version at: http://dx.doi.org/10.1002/1099-131X(200104)20:3<181::AID-FOR781>3.0.CO;2-R

To link to this article DOI: $\mathrm{http}: / / \mathrm{dx}$.doi.org/10.1002/1099-

131X(200104)20:3<181::AID-FOR781>3.0.CO;2-R

Publisher: Wiley

All outputs in CentAUR are protected by Intellectual Property Rights law, including copyright law. Copyright and IPR is retained by the creators or other copyright holders. Terms and conditions for use of this material are defined in the End User Agreement.

www.reading.ac.uk/centaur 


\section{CentAUR}

Central Archive at the University of Reading

Reading's research outputs online 
This is the Author's Accepted Manuscript of a paper published in the Journal of Forecasting. The definitive version is available at www3.interscience.wiley.com 
Bicorrelations and Cross-Bicorrelations as Nonlinearity Tests and Tools for Exchange Rate Forecasting

Chris Brooks ${ }^{1}$, ISMA Centre, University of Reading and Melvin J. Hinich, University of Texas at Austin

1 Brooks (Corresponding author), ISMA Centre, P.O. Box 242, The University of Reading, Whiteknights, Reading RG6 6BA, England, Tel. (+44) 1189316768 (direct);

Fax: (+44) 11893147 41; e-mail: C.Brooks@ reading.ac.uk 


\title{
Bicorrelations and Cross-Bicorrelations as Nonlinearity Tests and Tools for Exchange Rate Forecasting
}

\begin{abstract}
This paper proposes and implements a new methodology for forecasting time series, based on bicorrelations and cross-bicorrelations. It is shown that the forecasting technique arises as a natural extension of, and as a complement to, existing univariate and multivariate nonlinearity tests. The formulations are essentially modified autoregressive or vector autoregressive models respectively, which can be estimated using ordinary least squares. The techniques are applied to a set of high frequency exchange rate returns, and their out of sample forecasting performance is compared to that of other time series models.
\end{abstract}

J.E.L. Classifications: C32, C53, F31

Keywords: forecasting, nonlinear, exchange rates, bicorrelations, cross-bicorrelations, time series modelling 
Author's biography:

Chris Brooks is a Reader in Financial Econometrics at the ISMA Centre, University of Reading, where he also obtained his PhD. His research interests are in the field of financial econometrics and financial risk management, where he has published widely. 


\section{Introduction}

Over the past decade and a half, a number of researchers have sought to consider the out of sample forecasting performance of structural models of exchange rate determination vis à vis atheoretical time series models (see, for example, Meese and Rogoff, 1983, 1986; Boughton, 1987; Boothe and Glassman, 1987). Although the jury is still out on the usefulness of structural models in this regard, the weight of evidence suggests that structural models are at best capable of marginal improvements in out of sample forecasting accuracy for monthly or quarterly exchange rates.

When the foreign exchange data is sampled at higher frequencies, however, structural models are of even less use since the explanatory variables, such as ratios of relative prices, outputs, inflation rates etc. are measured on a monthly basis at best. So how can we model intra-daily foreign exchange rate movements? If structural modelling is ruled out, we must turn our attention to time series modelling as a plausible alternative. There is some evidence that financial market participants use price histories to make predictions of future values. Allen and Taylor (1989), for example, find using a survey that $90 \%$ of respondents used some form of chartism in helping to form forecasts at horizons of up to one week. Numerous other studies have also found strong support for technical analysis, both from the point of wide application in the markets (Frankel and Froot, 1990), and also from the point of view of producing surprisingly (at least surprising to most academics) accurate forecasts (Pruitt and White, 1988, 1989; Brock et al., 1992). An important recent paper by Clyde and Osler (1997) has also made a link between technical analysis and nonlinear forecasting. They argue that technical analysis can be viewed as a simple way of exploring the nonlinear behaviour of financial time series. Clyde and Osler demonstrate that the use of technical analysis can generate higher profits than a random trading strategy if the true data generating process is not linear. These observations give a strong motivation for the consideration of time series models of price histories for forecasting financial asset prices or returns. 
Nonlinearity is now an accepted stylised fact of financial market returns. Hinch and Patterson (1985), Hsieh (1991), Scheinkman and LeBaron (1989), Mayfield and Mizrach (1992), Brooks (1996), and Hsieh (1989), for example, all find strong evidence of nonlinearity in various asset returns series. The latter two authors also find that significant nonlinearity remains in the series after allowing for volatility clustering effects, the feature to which most of the nonlinear behaviour is attributed. This finding seems at odds with the observation that nonlinear forecasting models seem unable to give superior out-of-sample forecasts for the conditional mean equation (see Brooks, 1997 or Ramsey, 1996) compared with linear models or the naive random walk. If the nonlinearity is present in the data, why do nonlinear time series models not outperform their linear counterparts?

One way to reconcile these two findings lies in the very essence of the nonlinearity tests that have become popular in recent years, and that is their portmanteau or general nature. Tests such as the BDS (Brock et al., 1987, 1996), bispectrum (Hinich, 1982), RESET (Ramsey, 1969) or neural network tests (White, 1990, Lee et al., 1993) for nonlinearity all have independence and identical distribution of the residuals of an estimated linear model as their null, but do not have a specific alternative hypothesis - that is, they are pure hypothesis tests. Thus a rejection of the null gives the researcher little clue as to what the appropriate functional form for a nonlinear forecasting model should be. Various models have been considered (bilinear, SETAR, GARCH, neural network etc.), and of these, only the SETAR and GARCH models have any strong motivation from an underlying financial theory ${ }^{2}$. Thus it is possible, indeed perhaps even likely, that the specification of the nonlinear time series equations used for forecasting are not models of the type that caused the rejections of the linear or iid null in the nonlinearity tests in the first place. Of particular relevance here is the distinction between nonlinearity in mean and nonlinearity in variance. Campbell et al. (1996) provide a useful method of discriminating between the two: the Wold representation theorem

\footnotetext{
${ }^{2}$ GARCH models might capture autocorrelation in the rate of information arrival, and SETAR models might be applicable in the context of a financial market with transactions costs, so that returns can move within certain boundaries without triggering arbitrage trading since the costs of transacting would outweigh the benefits (see Yadav, Pope, and Paudyal, 1994)
} 
states that any stationary time series, $x_{t}$, can be expressed as an infinite order moving average of past innovations. A nonlinear extension of this which works for most models is to express them as

$$
x_{t}=g\left(\varepsilon_{t-1}, \varepsilon_{t-2}, \ldots\right)+\varepsilon_{t} h\left(\varepsilon_{t-1}, \varepsilon_{t-2}, \ldots\right)
$$

The square of $h$ is the conditional variance of $x_{t}$ so models with nonlinear $g$ are classified as nonlinear in mean, while those with nonlinear $h$ are classed as nonlinear in variance.

Many of the portmanteau tests listed above (with the possible exception of the bispectrum test) will lead to rejections of the iid null if there is nonlinearity in mean or in variance of a type which the particular test has power against. Most of the nonlinearity that is purported to be present in financial and economic time series can apparently be explained by reference to the latter type (see, for example, Hsieh, 1993), while models which attempt to forecast the conditional returns themselves obviously require the former.

Few researchers to date have considered extending the set of plausible "time series" models to the multivariate context. One exception is Mizrach (1992), who finds a multivariate nearest neighbours model has limited forecasting power for three EMS exchange rates. VAR models have also been used to forecast exchange rates (for example Hoque and Latif, 1993; Liu et al., 1994; Sarantis and Stewart, 1995; Tse, 1995). The first three applications have been "structural" (rather than time series in nature) and also linear. Tse, on the other hand, uses lagged futures returns to predict spot returns in a vector error correction framework, and finds the time series VAR to be preferable for forecasting compared with a univariate or martingale model, although the VAR is still outperformed by an error correction model.

Hinich (1996) and Brooks and Hinich (1999) propose a univariate test for nonlinearity and an extension to the multivariate case respectively. The tests are based on the computation of the bicorrelation coefficients of a series and the cross-bicorrelations between series at various lags. The central theme of the present paper is to build upon these earlier studies in a number of important 
regards. First, the paper collects together the univariate and multivariate tests and applies them in combination to a single set of data in order to facilitate comparisons. Second, it is demonstrated that the bicorrelation and cross-bicorrelation tests suggest a natural model class for forecasting future values of the series under consideration. These new forecasting techniques are also applied to the data, and their out of sample, multi-step ahead predictive accuracies are contrasted and evaluated.

A number of recent papers have considered the transmission of shocks to returns or to volatility between one market and another. Hamao et al. (1990), for example, consider spillovers of volatility between New York, Tokyo, and London stock markets using a GARCH-M model, while Engle et al. (1990) examine volatility transmission in high frequency exchange rates. Another facet of the methodology employed in the present study is that the results have implications for the speed and direction of the flow of information between exchange rates, since if lagged values of exchange rate $\mathrm{X}$ can be used with lagged values of $\mathrm{Y}$ to predict future values of $\mathrm{Y}$, then it appears that $\mathrm{X}$ reflects new information more quickly than $\mathrm{Y}^{3}$.

The remainder of this paper is organised as follows. Section 2 gives a description of the nonlinearity testing and forecasting techniques applied in this research, and section 3 presents the data. Section 4 outlines the results, and finally section 5 offers some concluding remarks.

\section{Methodology}

\subsection{Testing for Significant Bicorrelations and Cross-Bicorrelations}

The univariate and multivariate nonlinearity tests are constructed as below, closely following Hinich (1996) and Brooks and Hinich (1999). Let the data be a sample of length $N$, from two jointly stationary time series $\left\{x\left(t_{k}\right)\right\}$ and $\left\{y\left(t_{k}\right)\right\}$ which have been standardised to have a sample mean of zero and a sample variance of one by subtracting the sample mean and dividing by the sample standard deviation in each case. Since we are working with small sub-samples of the whole series, and the 
returns are constructed from data sampled at very high frequency, stationarity is not a stringent assumption.

For the univariate test, under the null hypothesis that the data $\left\{x\left(t_{k}\right)\right\}$ is a pure noise process, then there will be significant bicorrelations,

$$
\mathrm{E}\left[x\left(t_{k}\right) x\left(t_{k+r}\right) x\left(t_{k+s}\right)\right]=0
$$

The cross-bicorrelation generalisation of this simply implies that one of $x\left(t_{k+r}\right)$ or $x\left(t_{k+s}\right)$ is replaced with a $y$ so:

$$
\mathrm{E}\left[x\left(t_{k}\right) x\left(t_{k+r}\right) y\left(t_{k+s}\right)\right]=0
$$

We state without proof or further derivation that the bicorrelation and cross-bicorrelation test statistics can be written respectively as

$$
\begin{aligned}
& H_{x x x}(N)=\sum_{s=-L}^{L} \cdot \sum_{r=1}^{L}(N-m) C_{x x x}{ }^{2}(r, s), \quad('-s \neq 0) \\
& H_{x x y}(N)=\sum_{s=-L}^{L} \cdot \sum_{r=1}^{L}(N-m) C_{x x y}{ }^{2}(r, s), \quad('-s \neq 0)
\end{aligned}
$$

where

$$
\begin{aligned}
& C_{x x x}(r, s)=(N-m)^{-1} \sum_{t=1}^{N-m} x\left(t_{k}\right) x\left(t_{k}+r\right) x\left(t_{k}+s\right), \\
& C_{x x y}(r, s)=(N-m)^{-1} \sum_{t=1}^{N-m} x\left(t_{k}\right) x\left(t_{k}+r\right) y\left(t_{k}+s\right), m=\max (r, s), L=N^{c}(0<c<0.5) .
\end{aligned}
$$

$c$ is a parameter under the choice of the user. Based upon Monte Carlo simulations in Hinich (1996), and $c=0.4$ is employed in this application in order to maximise the power of the test while still ensuring a valid approximation to the asymptotic theory. Theorem (1) of Hinich (1996) shows that $H_{x x x}$ is asymptotically chi-squared with degrees of freedom equal to the number of squares in the sum. Similar arguments could be used to demonstrate the asymptotic chi-squared distribution of the cross-

\footnotetext{
${ }^{3}$ So long as the predictability is not a spurious statistical artefact.
} 
bicorrelation test statistic, which has an equivalent number of degrees of freedom. See Brooks and Hinich (1999) for the corresponding proof in this case.

The bicorrelation is effectively a correlation between the current exchange rate return and previous autocorrelation coefficients, while the cross-correlation can be interpreted as a correlation between one exchange rate return ( $x$ or $y$ ) and the temporal (lead-lag) cross correlation between the two returns $\left(x\left(t_{k+r}\right) y\left(t_{k+s}\right)\right)$.

In this study, we employ a window length of 960 observations, corresponding to approximately four trading weeks, for the calculation of the nonlinearity test statistics. The year is then made up of 13 such, entirely independent, non-overlapping periods. The cross-bicorrelation test is conducted on all pair-wise combinations of the seven exchange rates (21 pairs). The bicorrelation test is used on the residuals of an autoregressive fit to the data, and the cross-bicorrelation test on the residuals from a VAR. This pre-filtering step should ensure that all traces of linear dependence and co-dependence respectively are removed from the series.

\subsection{Forecasting Using Cross-Bicorrelations}

A major benefit of the nonlinearity tests employed in this study relative to their competitors (such as the BDS test or its multivariate extension due to Baek and Brock, 1992), is that the test statistics are sufficiently general to pick up many types nonlinearity in the conditional mean (any that generate third-order dependence), and yet they also suggest an appropriate functional form for a nonlinear forecasting equation. Consider again equations (2) and (3). If we rewrite them using only lags of the observed variates, we would have bicorrelations and cross-bicorrelations as $\mathrm{E}[x(t) x(t-r) x(t-s)]$ and $\mathrm{E}[x(t) x(t-r) y(t-s)]$ respectively. For $r, s \in \mathrm{Z}^{+}$, then at time $t-k\left(k \in \mathrm{Z}^{+}\right)$, we know $x(t-r)$ and $x(t-s)$ or $y(t-s)$ and we can therefore use these terms in combination in a linear regression for forecasting the future path of $x_{t}$. If the maximum number of lags permitted is $K$, then the forecasting models would be given by 


$$
x_{t}=\mu+\sum_{i=1}^{K} \alpha_{i} x_{t-i}+\sum_{r=1}^{K} \sum_{s=1}^{K} \beta_{r s} x_{t-r} x_{t-s}+u_{t}
$$

for the univariate case, and for the multivariate extension, the appropriate forecasting model would be an augmented standard form VAR.

$$
\begin{aligned}
& x_{t}=\mu_{1}+\sum_{i=1}^{K} \alpha_{1 i} x_{t-i}+\sum_{j=1}^{K} \gamma_{1 j} y_{t-j}+\sum_{r=1}^{K} \sum_{s=1}^{K} \beta_{1 r s} x_{t-r} x_{t-s}+u_{1 t} \\
& y_{t}=\mu_{2}+\sum_{i=1}^{K} \alpha_{2 i} x_{t-i}+\sum_{j=1}^{K} \gamma_{2 j} y_{t-j}+\sum_{r=1}^{K} \sum_{s=1}^{K} \beta_{2 r s} x_{t-r} x_{t-s}+u_{2 t}
\end{aligned}
$$

where $u_{1 t}$ and $u_{2 t}$ are iid disturbances and the $\mu, \alpha, \gamma, \beta$ are regression parameters. Since these equations are linear in the parameters (although they involve multiplicative combinations of the variables), they can be estimated using ordinary least squares.

In this study, we experimented with various values of $K$, the number of lags, and $K=2$ seemed to give the best results overall. Other values of $K$ are, of course, equally sensible, but the results derived from these parameter choices yield poorer forecasts in this application, and hence are not shown due to space constraints. The sample is split approximately in half, with the first 6238 observations being used for in-sample parameter estimation, while the remainder of the observations are retained as a hold-out sample for post-model forecast evaluation. All models are then estimated using a moving window of length 6238 observations, working through the series one data point at a time. Although forecasts up to six steps ahead are produced, after 3 steps, almost all of the forecasting models, which are essentially autoregressive in nature, have produced forecasts which have converged upon those from a long term mean forecast, so that only the results for forecasts generated 1,2, and 3 steps ahead are shown in the appendix.

\section{2c Linear Models for Comparison}

In order to have an appropriate benchmark for comparison with the one step ahead forecasts generated by the cross-bicorrelation VAR model, forecasts are also produced using a long term 
historic mean (average of the last 6238 observations), a random walk in the log-levels (i.e. a zero return forecast), autoregressive models of order 1,3, and 10, and autoregressive models of order selected using information criteria. The generation of forecasts using all but the last of these is described in detail in Brooks (1997). Information criteria are used in the following manner. Autoregressive models of all orders from 0 to 10 are estimated, and models are selected which minimise the value of each criterion (Akaike's and Schwarz's Bayesian). Then one step ahead forecasts are calculated using each of these estimated models. The window moves through by one data point, and the values of the IC are calculated again, and the model orders which minimise each are selected, and so on. The purpose of this procedure is to allow the autoregressive models to be of an "optimal" order (in an in-sample sense), and for that order to be permitted to vary over the whole sample according to how much linear structure there is present in the recent return histories.

\section{Data}

The high frequency financial data provided by Olsen and Associates as part of the HFDF-96 package includes 25 exchange rate series sampled half-hourly for the whole of 1996, making a total of 17,568 observations for each series. However, this series contains observations corresponding to weekend periods when all the world's exchanges are closed simultaneously and there is, therefore, no trading. This period is the time from 23:00 GMT on Friday when North American financial centres close until 23:00 GMT on Sunday when Australasian markets open ${ }^{4}$. The incorporation of such prices would lead to spurious zero returns and would potentially render trading strategies which recommended a buy or sell at this time to be nonsensical. Removal of these weekend observations leaves 12,576 observations for subsequent analysis and forecasting. The price series are transformed into a set of continuously compounded half-hourly percentage returns in the standard fashion:

$$
r_{t}=100 \times \log \left(P_{t} / P_{t-1}\right)
$$

\footnotetext{
${ }^{4}$ We do not account for differences in the dates that different countries switch to daylight saving time, since the effect of this one-hour difference is likely to be negligible.
} 
Of the 25 exchange rate series provided by Olsen, only 7 are used in this study for illustrative purposes, to avoid repetition, and due to space constraints. These are (using the usual Reuters neumonic) DEM_JPY, GBP_DEM ${ }^{5}$, GBP_USD, USD_CHF, USD_DEM, USD_ITL, and USD_JPY. Summary statistics for these returns series are presented in table 1. It is clearly evident that all series are non-normal (predominantly due to fat tails rather than asymmetry), and all exhibit strong evidence of negative first order autocorrelation, and conditional heteroscedasticity (as the Ljung Box and Engle test respectively show). The BDS statistic therefore rejects the null hypothesis of independent and identical distribution at the $0.1 \%$ level of significance.

\section{Results}

\subsection{Nonlinearity Test Results}

The results of the bicorrelation and cross-bicorrelation tests applied to the thirteen 4-week windows are presented in tables 2 and 3 respectively. Given that the nominal threshold for determining whether a window is "significant" or not is $1 \%$, we would expect at most one window per exchange rate or exchange rate pair to have a significant $x x x, \quad x x y$ or $y y x$ test statistic. However, the results presented in table 2 show that most of the windows have significant bicorrelations $(x x x)$ windows for all seven series. The most extreme case is the US dollar / Italian lira, for which all 13 windows have significant bicorrelation test statistics at the $1 \%$ level. The results in the second column of table 3 also show that typically nearly half the windows have at least one of the two cross-bicorrelation test statistics being significant. The third column of table 2 and the third and fourth columns of table 3 show the month(s) during which the rejections of the null of independent white noise processes occurred. If we compare the times when the bicorrelation windows are significant with those when the cross-bicorrelation test trips for each currency, we find only limited agreement between the tests, indicating that univariate and multivariate nonlinearities in the data need not occur at the same time.

\footnotetext{
${ }^{5}$ Other users of this data should be aware that there are two erroneous price entries on 27 May 1996 at 13:30 and 14:00, where values of 3609.13 and 3609.22 appear respectively. These clearly represent incorrectly keyed in quotes, and hence both have been set to the immediately proceeding price.
} 
Moreover, when we apply the tests to the entire in-sample model construction period or the model testing period (i.e. the first and last half of the sample respectively), we find all exchange rates and exchange rate pairs give both bicorrelation and cross-bicorrelation coefficients that are significant at the $1 \%$ level. This is clear evidence in favour of the presence of univariate and multivariate nonlinearity in the conditional mean, which might potentially be predictable using the methodology outlined above ${ }^{6}$.

\subsection{Forecasting Results}

The results of the one step ahead forecasting approach using the linear and cross-bicorrelation models are presented for each exchange rate in tables 4 to 10. In order to facilitate comparison between forecasting methods, after each evaluation measure, (MSE, MAE or sign predictions), the ranking of each of the 15 forecasting models is given for that particular criterion. For example, an entry of $1=$ in the AR(1) column in the row immediately following the MSE would indicate that an AR(1) was jointly the best forecasting model for that particular series and forecasting horizon.

Considering first the mean squared error and mean absolute error evaluation criteria, there is little to choose between most of the linear models. Typically, an $\mathrm{AR}(1)$ or $\mathrm{AR}(3)$ gives the smallest overall error (MSE or MAE give the same model ordering), with exponential smoothing giving the largest. Exponential smoothing is a technique originally formulated for forecasting periodic, seasonal data, so it was not envisaged that it would perform particularly well for forecasting high frequency financial asset returns, which have very different properties to monthly sales data.

Interestingly, producing forecasts using "optimally" in-sample selected models using the information criteria does not seem worth the additional effort since they rarely give lower errors than a simple $\operatorname{AR}(1)$. The $\operatorname{AR}(1)$ is also almost always able to beat the long term average predictor at short

\footnotetext{
${ }^{6}$ Recall that the tests are computed on the residuals of an autoregressive or a VAR fit to the data so that the rejections of independent white noise processes cannot be attributed to linear autocorrelation or crosscorrelations.
} 
forecasting horizons, and, surprisingly, the random walk. This effect is likely to be largely attributable to the first order negative autocorrelation alluded to previously. Furthermore, according to these conventional statistical criteria, the new cross-bicorrelation models produce very much poorer forecasts than those of the linear model. Occasionally, some of the new models do better than the worst of the linear models, but they are almost never able to out-perform the $\operatorname{AR}(1)$. The univariate bicorrelation forecasting models, on the other hand, perform extremely well on conventional statistical criteria, particularly at short forecasting horizons, although their forecasting power deteriorates relative to their competitors as the horizon increases. The bicorrelation models are the best 1 step-ahead predictors of 15 forecasting methods for 4 of the 7 currencies when MSE is used, and for 2 of 7 when the forecast evaluation method is MAE.

However, the inability of traditional forecast evaluation criteria to select models which produce positive risk adjusted trading profits is well documented (see, for example Gerlow et al., 1993). Models which can accurately predict the sign of future asset returns (irrespective of the size) are, however, more likely to produce profitable trading performances than those which do well on MSE grounds. Thus the proportion of times that the forecast has the correct sign is given in the last row of each panel of each table. For the linear models, the story is very similar to that given above - that is, there is very little to choose between most of the models, which produce almost the same proportion of correct sign predictions, although the long term mean and exponential smoothing are worst and the $\mathrm{AR}(1)$ is generally (although now not universally) superior.

The results for the cross-bicorrelation models in this regard are somewhat mixed, although considerably more favourable than those evaluated on traditional statistical grounds. The proportion of correctly predicted signs rises as high as $60 \%$ (for the USD_DEM cross-bicorrelation helping to predict the DEM_JPY), but it also falls as low as $40 \%$ (for the USD_DEM predicting the USD_CHF). 
So which exchange rates can be used to predict which others? It seems that when the crossbicorrelation between two exchange rates can be used to predict the next sign of one of them, it can also be used to predict the sign of the other, so that predictability seems to flow in both directions or not at all $^{7}$. It seems that the USD_CHF, USD_DEM and USD_ITL can be used to predict the DEM_JPY; the USD_CHF, USD_DEM, USD_ITL and USD_JPY can be used to predict the GBP_USD; the DEM_JPY and GBP_USD can be used to predict the USD_CHF; the DEM_JPY and GBP_USD can be used to predict the USD_DEM; the DEM_JPY and GBP_USD can be used to predict the USD_ITL, and the GBP_USD can be used to predict the USD_JPY. None of the crossbicorrelation combinations investigated here could help to forecast the GBP_DEM.

It was expected that lager trading-volume exchange rates (such as the USD_JPY, or the USD_DEM) might have predictive power for smaller trading volume rates (such as the USD_ITL), indicating that information was more quickly reflected in these larger-volume series so that they seemed to have predictive power for the smaller volume series. But the empirical results shown here seem only to partially support this conjecture. Moreover, it is not clear that whether a given currency is on one side of a cross-rate means it is a better predictor of another exchange rate which also contains this currency on one side (e.g. is the USD_DEM a better predictor of the USD_ITL than the GBP_DEM?).

\section{Conclusions}

This paper has proposed a simple methodology which can be used to unify the currently popular time series nonlinearity testing and forecasting literature. The bicorrelation and cross-bicorrelation forecasting models are assessed on three different statistical measures. Although the forecasting results derived from these models do not represent a universal improvement in accuracy, they do sometimes lead to forecast improvements worthy of further research effort. It is possible that by refining the timing of the bicorrelation forecasting rules (so that, for example, we only use a

\footnotetext{
${ }^{7}$ This is partly indicated by the interesting degree of symmetry in the right had side of table 10 about the leading
} 
bicorrelation forecasting model when the last estimation window in sample yields a significant bicorrelation or cross-bicorrelation), or by determining the appropriate number of lags in sample in a more "optimal" fashion, that the forecasting results might be further improved. We should also draw a distinction between the performances of the univariate and multivariate forecasting models. The pure bicorrelation models produced perhaps the most accurate short term forecasts of all the methods employed, yet they were of limited use in terms of sign prediction. On the other hand, the crossbicorrelation forecasting models lead to very poor mean squared and mean absolute errors, but higher sign hit rates. A closer inspection of the forecasts from these models suggests that the forecasts are, on average, in the right direction more often than other methods, but are further away in terms of point accuracy.

Nonlinearity testing has become extremely popular in the applied financial econometrics literature in recent years, as the statistical tools have developed along side great advances in computing power. However, further developments in the application of these tests are likely to be limited by the pure hypothesis testing nature of the extant tests. Therefore, further study of more specific nonlinearity tests, which automatically suggest an appropriate parametric forecasting model is, we conjecture, likely to be a fruitful avenue for future research effort.

diagonal of dashes starting with CVAR DEM_JPY. 


\section{References}

Allen, H and Taylor, M.P. (1989) Chart Analysis and the Foreign Exchange Market Review of Futures Markets 8(2), 288-319

Baek, E. and Brock, W.A. (1992) A Nonparametric Test for Independence of a Multivariate Time Series, Statistica Sinica 2, 137-156

Boothe, P. and Glassman, D. (1987) Comparing Exchange Rate Forecasting Models: Accuracy Versus Profitability. International Journal of Forecasting 3, 65-79

Boughton, J.M. (1987) Tests of the Performance of Reduced-Form Exchange Rate Models Journal of International Economics 23, 41-56

Brock, W.A., Dechert, W.D., and Scheinkman, J.A. (1987) A Test for Independence Based on the Correlation Dimension Mimeo. Department of Economics, University of Wisconsin at Madison, and University of Houston

Brock, W.A., Dechert, W.D., Scheinkman, J.A. and LeBaron (1996) A Test for Independence Based on the Correlation Dimension Econometric Reviews 15, 197-235

Brock, W.A., Lakonishok, J. and LeBaron, B. (1992) Simple Technical Trading Rules and the Stochastic Properties of Stock Returns Journal of Finance 47, 1731-1764

Brooks, C. (1997) Linear and Nonlinear (Non-) Forecastability of Daily Sterling Exchange Rates Journal of Forecasting 16, 125-145

Brooks, C. (1996) Testing for Nonlinearity in Daily Pound Exchange Rates Applied Financial Economics 6, 307-317

Brooks, C. and Hinich, M.J. (1999) Cross-Correlations and Cross-Bicorrelations in Sterling Exchange Rates forthcoming in Journal of Empirical Finance

Campbell, J.Y., Lo, A.W., and MacKinlay, A.C. (1997) The Econometrics of Financial Markets Princeton University Press, Princeton NJ

Clyde, W.C. and Osler, C.L. (1997) Charting: Chaos Theory in Disguise? Journal of Futures Markets 17(5), 489-514

Engle, R.F., Ito, T. and Lin, W-L. (1990) Meteor Showers or Heat Waves? Heteroskedastic IntraDaily Volatility in the Foreign Exchange Market Econometrica 58(3), 525-542

Frankel, J.A. and Froot, K.A. (1990) Chartists, Fundamentalists, and Trading in the Foreign Exchange Market AEA Papers and Proceedings 181-185

Hamao, Y, Masulis, R.W., and Ng, V.K. (1990) Correlations in Price Changes and Volatility Across International Stock Markets Review of Financial Studies 3(2), 281-307

Hinich, M.J. (1996) Testing for Dependence in the Input to a Linear Time Series Model Journal of Nonparametric Statistics 6, 205-221

Hinich, M.J. (1982) Testing for Gaussianity and Linearity of a Stationary Time Series Journal of Time Series Analysis 3(3), 169-176 
Hinich, M.J. and Patterson, D.M. (1985) Evidence of Nonlinearity in Daily Stock Returns Journal of Business and Economic Statistics 3(1), 69-77

Hoque, A. and Latif, A. (1993) Forecasting Exchange Rate for the Australian Dollar vis-a-vis US Dollar Using Multivariate Time Series Models Applied Economics 25, 403-407

Hsieh, D.A. (1993) Implications of Nonlinear Dynamics for Financial Risk Management Journal of Financial and Quantitative Analysis 28(1), 41-64

Hsieh, D.A. (1989) Testing For Nonlinear Dependence in Daily Foreign Exchange Rates Journal of Business 62(3), 339-368

Karolyi, G.A. and Stulz, R.M. (1996) Why Do Markets Move Together? An Investigation of U.S.Japan Stock Return Comovements Journal of Finance 51, 951-986

Lee, T., White, H. and Granger, C.W.J. (1993) Testing for Neglected Nonlinearity in Time Series Models: A Comparison of Neural Network Methods and Alternative Tests Journal of Econometrics 56, 269-290

Liu, T-R., Gerlow, M.E., and Irwin, S.H. (1994) The Performance of Alternative VAR Models in Forecasting Exchange Rates International Journal of Forecasting 10, 419-433

Mayfield, E.S. and Mizrach, B. (1992) On Determining the Dimension of Real-Time Stock-Price Data Journal of Business and Economic Statistics 10(3), 367-374

Meese, R.A. and Rogoff, K. (1986) Was it Real? The Exchange Rate-Interest Differential Relation over the Modern Floating-Rate Period The Journal of Finance 43(4), 933-948

Meese, R.A. and Rogoff, K (1983) Empirical Exchange Rate Models of the Seventies: Do they Fit Out of Sample? Journal of International Economics 14, 3-24

Mizrach, B. (1992) Multivariate Nearest Neighbour Forecasts of EMS Exchange Rates Journal of Forecasting 7, S151-S163

Pruitt, S.W. and White, R.E. (1988) The CRISMA Trading System: Who Says Technical Analysis Can't Beat the Market? Journal of Portfolio Management, 14(3), 55-58

Pruitt, S.W. and White, R.E. (1989) Exchange-Traded Options and CRISMA Trading Journal of Portfolio Management 15(4), 55-56

Ramsey, J.B. (1996) If Nonlinear Models Cannot Forecast, What Use are They? SNDE 1(2), 1-43

Ramsey, J.B. (1969) Tests for Specification Errors in Classical Linear Least-Squares Regression Analysis Journal of the Royal Statistical Society B 31(2), 350-371

Sarantis, N. and Stewart, C. (1995) Structural VAR and BVAR Models of Exchange Rate Determination: A Comparison of their Forecasting Performance Journal of Forecasting 14, 205-215

Scheinkman, J.A. and LeBaron, B. (1989) Nonlinear Dynamics and Stock Returns Journal of Business 62(3), 311-337 
Tse, Y.K. (1995) Lead-Lag Relationship Between Spot and Index Futures Price of the Nikkei Stock Average Journal of forecasting 14, 553-563

White, H. (1990) Connectionist Nonparametric Regression: Multilayered Feedforward Networks Can Learn Arbitrary Mappings Neural Networks 3, 535-550

Yadav, P.K., P.F. Pope and K. Paudyal, (1994) Threshold autoregressive modelling in finance : the price difference of equivalent assets, Mathematical Finance 4, 205-221 
Table 1: Summary Statistics for Half-Hourly Exchange Rate Returns

\begin{tabular}{|c|c|c|c|c|c|c|c|}
\hline & $\begin{array}{c}\text { DEM_ } \\
\text { JPY }\end{array}$ & $\begin{array}{l}\text { GBP } \\
\text { DEM }\end{array}$ & $\begin{array}{c}\text { GBP }_{-} \\
\text {USD }\end{array}$ & $\begin{array}{l}\text { USD_- } \\
\text { CHF }\end{array}$ & $\begin{array}{l}\text { USD_ }_{-} \\
\text {DEM }\end{array}$ & $\begin{array}{l}\text { USD_ } \\
\text { ITL }\end{array}$ & $\begin{array}{c}\text { USD_ } \\
\text { JPY }\end{array}$ \\
\hline Mean & $3.4 \mathrm{E}-4$ & $9.7 \mathrm{E}-4$ & $5.6 \mathrm{E}-4$ & 8.6E-4 & $4.5 \mathrm{E}-4$ & $-2.1 \mathrm{E}-4$ & $6.5 \mathrm{E}-4$ \\
\hline Variance & $6.5 \mathrm{E}-3$ & $4.6 \mathrm{E}-3$ & $4.8 \mathrm{E}-4$ & $8.5 \mathrm{E}-3$ & $5.1 \mathrm{E}-3$ & $9.0 \mathrm{E}-3$ & $6.2 \mathrm{E}-3$ \\
\hline Skewness & -0.049 & -0.004 & -0.167 & -0.156 & -0.190 & -0.011 & -0.019 \\
\hline Kurtosis & 5.642 & 99.373 & 25.414 & 79.408 & 25.105 & 15.719 & 9.723 \\
\hline Minimum & -0.707 & -1.966 & -1.137 & -2.431 & -1.020 & -0.924 & -0.770 \\
\hline Maximum & 0.659 & 1.992 & 1.203 & 2.403 & 0.973 & 0.966 & 0.758 \\
\hline acf lag 1 & -0.198 & -0.306 & -0.205 & -0.189 & -0.097 & -0.315 & -0.150 \\
\hline acf lag 2 & -0.013 & -0.0053 & -0.001 & -0.004 & 0.005 & -0.019 & -0.002 \\
\hline acf lag 3 & 0.008 & 0.007 & -0.000 & 0.002 & 0.015 & -0.000 & 0.005 \\
\hline acf lag 4 & -0.006 & 0.000 & 0.004 & -0.009 & -0.005 & -0.005 & -0.008 \\
\hline acf lag 5 & 0.006 & 0.004 & -0.000 & 0.032 & 0.002 & -0.017 & -0.005 \\
\hline LB-Q(10) & $500 * *$ & $3144 * *$ & $536 * *$ & $476^{* *}$ & $129 * *$ & $1261 * *$ & $288 * *$ \\
\hline $\mathrm{ARCH}(4)$ & $601.1 * *$ & $23.6^{* *}$ & $1355^{* *}$ & $2559 * *$ & $693 * *$ & $1616 * *$ & $462 * *$ \\
\hline BJ Norm & $4 \mathrm{E}+5 * *$ & $2 \mathrm{E}+10 * *$ & $9 \mathrm{E}+4 * *$ & $3 \mathrm{E}+6 * *$ & $7 \mathrm{E}+4 * *$ & $9 \mathrm{E}+4 * *$ & $2 \mathrm{E}+4 * *$ \\
\hline BDS & $32.47 * *$ & $30.68 * *$ & $41.00 * *$ & $37.52 * *$ & $38.95 * *$ & $44.12 * *$ & $33.27 * *$ \\
\hline$\%$ zeros & 7.5 & 6.1 & 5.0 & 5.7 & 5.1 & 5.4 & 4.9 \\
\hline
\end{tabular}

Notes: Kurtosis represents excess kurtosis, LB-Q(10) is a Ljung Box test for autocorrelation of all orders up to 10 , and is asymptotically distributed as a $\chi^{2}(10)$ under the null hypothesis; $\mathrm{ARCH}(4)$ is Engle's (1982) Lagrange multiplier test for $\mathrm{ARCH}$ which is asymptotically distributed as a $\chi^{2}(4)$; BJ norm is the Bera Jarque normality test, which is asymptotically distributed as a $\chi^{2}$ (2) under the null of normality; BDS is the Brock, Dechert, and Scheinkman (1987) test for iid, which is distributed asymptotically as a standard normal under the null (statistic shown is for $m=5$ and $\varepsilon / \sigma=1$ ); $\%$ zeros gives the percentage of returns that are zero (i.e. no price change).

Table 2: Bicorrelation Test Results

\begin{tabular}{|c|c|c|}
\hline Series & $\begin{array}{l}\text { Number (\%) Significant } \\
\text { Bicorrelation Windows }\end{array}$ & Dates of Significant Windows \\
\hline DEM_JPY & $10(76.9 \%)$ & $\begin{array}{l}\text { Jan, Jan/Feb, Feb/Mar, Mar/Apr, May/Jun, Jun/Jul, Jul/Aug, } \\
\text { Oct/Nov, Nov / Dec, Dec }\end{array}$ \\
\hline GBP_DEM & $11(84.6 \%)$ & $\begin{array}{c}\text { Jan, Jan/Feb, Feb/Mar, Mar/Apr, Apr/May, May/Jun, Jul/Aug, } \\
\text { Aug/Sep, Sep/Oct, Oct/Nov, Dec }\end{array}$ \\
\hline GBP_USD & $10(76.9 \%)$ & $\begin{array}{l}\text { Feb/Mar, Mar/Apr, Apr/May, May/Jun, Jun/Jul, Jul/Aug, } \\
\text { Aug/Sep, Sep/Oct, Oct/Nov, Dec }\end{array}$ \\
\hline USD_CHF & $12(92.3 \%)$ & $\begin{array}{c}\text { Jan, Feb/Mar, Mar/Apr, Apr/May, May/Jun, Jun/Jul, Jul/Aug, } \\
\text { Aug/Sep, Sep/Oct, Oct/Nov, Nov / Dec, Dec }\end{array}$ \\
\hline USD_DEM & $11(84.6 \%)$ & $\begin{array}{l}\text { Jan, Jan/Feb, Feb/Mar, Mar/Apr, Apr/May, May/Jun, Jun/Jul, } \\
\text { Jul/Aug, Aug/Sep, Sep/Oct, Oct/Nov, Nov / Dec, Dec }\end{array}$ \\
\hline USD_ITL & $13(100 \%)$ & $\begin{array}{l}\text { Jan, Jan/Feb, Feb/Mar, Mar/Apr, Apr/May, May/Jun, Jun/Jul, } \\
\text { Jul/Aug, Aug/Sep, Sep/Oct, Oct/Nov, Nov / Dec, Dec }\end{array}$ \\
\hline USD_JPY & $11(84.6 \%)$ & $\begin{array}{c}\text { Jan, Jan/Feb, Feb/Mar, Apr/May, May/Jun, Jun/Jul, Jul/Aug, } \\
\text { Aug/Sep, Oct/Nov, Nov / Dec, Dec }\end{array}$ \\
\hline \multicolumn{3}{|c|}{ 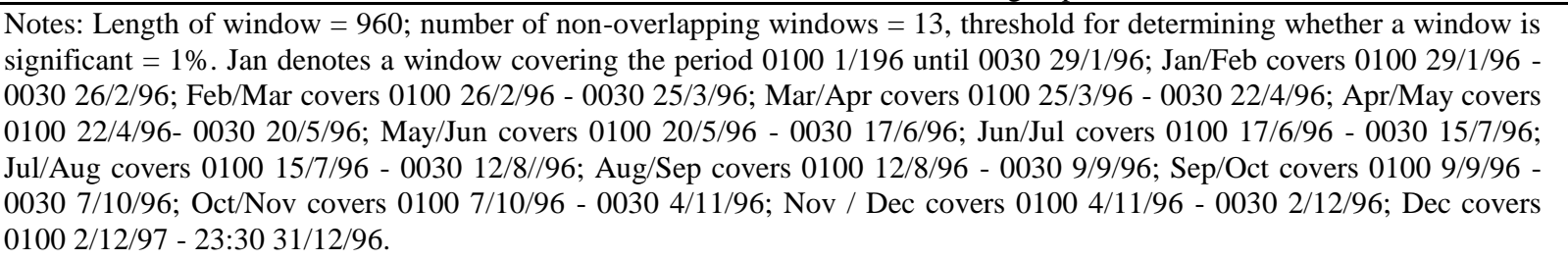 } \\
\hline
\end{tabular}


Table 3: Cross-Bicorrelation Test Results

\begin{tabular}{|c|c|c|c|}
\hline \multirow{2}{*}{$\begin{array}{l}\text { Exchange Rate } \\
\text { Combination } \\
(x \& y)\end{array}$} & \multirow{2}{*}{$\begin{array}{l}\text { No. }(\%) \text { sig. } \\
\text { cross- } \\
\text { bicorrelation } \\
\text { winds. }\end{array}$} & \multicolumn{2}{|c|}{ Dates of Significant windows for } \\
\hline & & xxy statistics & yyx statistics \\
\hline $\begin{array}{l}\text { DEM_JPY \& } \\
\text { GBP_DEM }\end{array}$ & $5(38.5)$ & Mar/Apr,Oct/Nov,Dec & $\begin{array}{c}\text { Feb/Mar,Mar/Apr,Sep/Oct, } \\
\text { Oct/Nov }\end{array}$ \\
\hline $\begin{array}{l}\text { DEM_JPY \& } \\
\text { GBP_USD }\end{array}$ & $4(30.8)$ & Mar/Apr,Oct/Nov & $\begin{array}{c}\text { Mar/Apr,Apr/May, } \\
\text { Jul/Aug,Oct/Nov }\end{array}$ \\
\hline $\begin{array}{l}\text { DEM_JPY \& } \\
\text { USD_CHF }\end{array}$ & $4(30.8)$ & Mar/Apr & Sep/Oct,Oct/Nov,Dec \\
\hline $\begin{array}{l}\text { DEM_JPY \& } \\
\text { USD_DEM }\end{array}$ & $7(53.8)$ & Jan/Feb,Mar/Apr,Oct/Nov,Dec & $\begin{array}{c}\text { Mar/Apr,Apr/MayMay/Jun, } \\
\text { Sep/Oct,Oct/Nov }\end{array}$ \\
\hline $\begin{array}{l}\text { DEM_JPY \& } \\
\text { USD_ILP }\end{array}$ & $5(38.5)$ & Aug/Sep,Oct/Nov & $\begin{array}{c}\text { Jan/Feb,Mar/Apr,Apr/May, } \\
\text { Aug/Sep,Oct/Nov }\end{array}$ \\
\hline $\begin{array}{l}\text { DEM_JPY \& } \\
\text { USD_JPY }\end{array}$ & $5(38.5)$ & $\begin{array}{c}\mathrm{Jan} / \mathrm{Feb}, \mathrm{Mar} / \mathrm{Apr}, \mathrm{Aug} / \mathrm{Sep}, \\
\text { Oct/Nov }\end{array}$ & $\begin{array}{c}\text { Jan/Feb,Mar/Apr,Aug/Sep, } \\
\text { Sep/Oct,Oct/Nov }\end{array}$ \\
\hline $\begin{array}{l}\text { GBP_DEM \& } \\
\text { GBP_USD }\end{array}$ & $5(38.5)$ & Jan/Feb,Mar/Apr,Aug/Sep,Oct/Nov & Mar/Apr,Sep/Oct,Oct/Nov \\
\hline $\begin{array}{l}\text { GBP_DEM \& } \\
\text { USD_CHF }\end{array}$ & $5(38.5)$ & $\begin{array}{l}\text { Jan/Feb,Aug/Sep, } \\
\text { Sep/Oct,Oct/Nov }\end{array}$ & Sep/Oct,Oct/Nov,Dec \\
\hline $\begin{array}{l}\text { GBP_DEM \& } \\
\text { USD_DEM }\end{array}$ & $4(30.8)$ & $\begin{array}{c}\text { Jan/Feb,Aug/Sep, } \\
\text { Oct/Nov }\end{array}$ & Mar/Apr,Oct/Nov \\
\hline $\begin{array}{l}\text { GBP_DEM \& } \\
\text { USD_ILP }\end{array}$ & $6(46.2)$ & $\begin{array}{l}\text { Mar/Apr,Apr/May, } \\
\text { Aug/Sep,Oct/Nov }\end{array}$ & $\begin{array}{c}\text { Jan,Mar/Apr,Jun/Jul, } \\
\text { Oct/Nov }\end{array}$ \\
\hline $\begin{array}{l}\text { GBP_DEM \& } \\
\text { USD_JPY }\end{array}$ & $7(53.8)$ & $\begin{array}{l}\text { Jan/Feb,Jul/Aug,Aug/Sep, } \\
\text { Sep/Oct,Oct/Nov,Dec }\end{array}$ & $\begin{array}{c}\text { Jan/Feb,Mar/Apr,Sep/Oct, } \\
\text { Oct/Nov }\end{array}$ \\
\hline $\begin{array}{l}\text { GBP_USD \& } \\
\text { USD_CHF }\end{array}$ & $7(53.8)$ & $\begin{array}{c}\text { Feb/Mar,Mar/Apr,May/Jun, } \\
\text { Aug/Sep }\end{array}$ & $\begin{array}{c}\text { Mar/Apr,Aug/SepOct/Nov, } \\
\text { Nov/Dec,Dec }\end{array}$ \\
\hline $\begin{array}{l}\text { GBP_USD \& } \\
\text { USD_DEM }\end{array}$ & $8(61.5)$ & $\begin{array}{l}\text { Feb/Mar,Mar/Apr,May/Jun, } \\
\text { Aug/Sep,Oct/Nov,Dec }\end{array}$ & $\begin{array}{c}\text { Mar/Apr,Apr/MayMay/Jun, } \\
\text { Sep/Oct,Oct/Nov }\end{array}$ \\
\hline $\begin{array}{l}\text { GBP_USD \& } \\
\text { USD_ILP }\end{array}$ & $3(23.1)$ & Oct/Nov,Dec & Mar/Apr,Oct/Nov \\
\hline $\begin{array}{l}\text { GBP_USD \& } \\
\text { USD_JPY }\end{array}$ & $4(30.8)$ & Feb/Mar,Mar/Apr,Oct/Nov & Mar/Apr,Oct/Nov,Dec \\
\hline $\begin{array}{l}\text { USD_CHF \& } \\
\text { USD_DEM }\end{array}$ & $8(61.5)$ & $\begin{array}{c}\text { Jan/Feb,Mar/Apr,May/Jun, } \\
\text { Jun/Jul,Aug/Sep,Oct/Nov,Nov/Dec }\end{array}$ & $\begin{array}{l}\text { Jan/Feb,Mar/Apr, } \\
\text { Sep/Oct,Oct/Nov }\end{array}$ \\
\hline $\begin{array}{l}\text { USD_CHF \& } \\
\text { USD_ILP }\end{array}$ & $7(53.8)$ & $\begin{array}{c}\text { Jan/Feb,May/Jun,Jun/Jul, } \\
\text { Aug/Sep,Oct/Nov }\end{array}$ & $\begin{array}{c}\text { Jan/Feb,Mar/Apr,Jun/Jul, } \\
\text { Sep/Oct,Oct/Nov }\end{array}$ \\
\hline $\begin{array}{l}\text { USD_C̄HF \& } \\
\text { USD_JPY }\end{array}$ & $7(53.8)$ & $\begin{array}{l}\text { Jan/Feb,Mar/Apr,May/Jun, } \\
\text { Aug/Sep,Sep/Oct,Nov/Dec }\end{array}$ & Mar/Apr,Aug/Sep,Oct/Nov \\
\hline $\begin{array}{l}\text { USD_DEM \& } \\
\text { USD_ILP }\end{array}$ & $6(46.2)$ & $\begin{array}{c}\text { Jan/Feb,Mar/Apr,Jul/Aug, } \\
\text { Aug/Sep,Oct/Nov }\end{array}$ & Jan/Feb,Mar/Apr,Jun/Jul, \\
\hline $\begin{array}{l}\text { USD_DEM \& } \\
\text { USD_JPY }\end{array}$ & $4(30.8)$ & Jan/Feb,Mar/Apr,Oct/Nov & $\begin{array}{c}\text { Jan/Feb,Mar/Apr,Jun/Jul, } \\
\text { Oct/Nov }\end{array}$ \\
\hline $\begin{array}{l}\text { USD_ILP \& } \\
\text { USD_JPY }\end{array}$ & $6(46.2)$ & $\begin{array}{l}\text { Mar/Apr,Jun/Jul,Aug/Sep, } \\
\text { Sep/Oct,Oct/Nov,Nov/Dec }\end{array}$ & Mar/Apr,Sep/Oct,Oct/Nov \\
\hline $\begin{array}{l}\text { Notes: Length of winc } \\
\text { significant }=1 \% \text {. Jan } \\
0030 \text { 26/2/96; Feb/Ma } \\
010022 / 4 / 96-00302 \\
\text { Jul/Aug covers } 0100 \\
0030 \text { 7/10/96; Oct/No } \\
01002 / 12 / 97-23: 30\end{array}$ & $\begin{array}{l}960 ; \text { number o } \\
\text { es a window co } \\
\text { ers } 010026 / 2 / 9 \\
6 \text {; May/Jun cov } \\
6 \text { - } 003012 / 8 / \\
\text { ers } 01007 / 10 /\end{array}$ & $\begin{array}{l}\text { n-overlapping windows }=13 \text {, threshold } \\
\text { ing the period } 01001 / 196 \text { until } 003029 \\
0030 \text { 25/3/96; Mar/Apr covers } 010025 \text { / } \\
0100 \text { 20/5/96 - } 003017 / 6 / 96 ; \text { Jun/Jul } \\
\text { Aug/Sep covers } 010012 / 8 / 96-0030 \\
0030 \text { 4/11/96; Nov / Dec covers } 0100\end{array}$ & $\begin{array}{l}\text { determining whether a window is } \\
6 \text {; Jan/Feb covers } 0100 \text { 29/1/96 } \\
\text { - } 0030 \text { 22/4/96; Apr/May covers } \\
\text { rs } 010017 / 6 / 96 \text { - } 0030 \text { 15/7/96; } \\
6 \text {; Sep/Oct covers } 0100 \text { 9/9/96 - } \\
1 / 96 \text { - } 0030 \text { 2/12/96; Dec covers }\end{array}$ \\
\hline
\end{tabular}


Table 4: Forecasting Performance for German Mark / Japanese Yen

\begin{tabular}{|c|c|c|c|c|c|c|c|c|c|c|c|c|c|c|c|}
\hline & mean & r.w & 1 & $\begin{array}{c}\mathrm{R} \text { of ord } \\
3\end{array}$ & 10 & $\begin{array}{l}\text { AR- } \\
\text { AIC }\end{array}$ & $\begin{array}{l}\text { AR- } \\
\text { SIC }\end{array}$ & Bicorr. & $\begin{array}{c}\text { Exp. } \\
\text { Smooth }\end{array}$ & $\begin{array}{l}\text { CVAR } \\
\text { GBP_- } \\
\text { DEM }\end{array}$ & $\begin{array}{l}\text { CVAR } \\
\text { GBP }_{-} \\
\text {USD }\end{array}$ & $\begin{array}{l}\text { CVAR } \\
\mathrm{USD}_{-} \\
\mathrm{CHF}\end{array}$ & $\begin{array}{l}\text { CVAR } \\
\mathrm{USD}_{-} \\
\text {DEM }\end{array}$ & $\begin{array}{c}\text { CVAR } \\
\text { USD_- } \\
\text { ITL }\end{array}$ & $\begin{array}{c}\text { CVAR } \\
\text { USD_- } \\
\text { JPY }\end{array}$ \\
\hline \multicolumn{16}{|c|}{ Panel A: 1 Step Ahead } \\
\hline MSE & 6.06 & 6.07 & 5.86 & 5.84 & 5.86 & 5.86 & 5.85 & 5.84 & 6.10 & 33.01 & 35.98 & 34.52 & 36.41 & 33.70 & 42.87 \\
\hline Rank & 7 & 8 & $4=$ & $1=$ & $4=$ & $4=$ & 3 & $1=$ & 9 & 10 & 13 & 12 & 14 & 11 & 15 \\
\hline MAE & 5.38 & 5.38 & 5.31 & 5.30 & 5.31 & 5.31 & 5.30 & 5.30 & 5.40 & 12.81 & 13.49 & 13.12 & 13.54 & 12.94 & 14.62 \\
\hline Rank & $7=$ & $7=$ & $4=$ & $1=$ & $4=$ & $4=$ & $1=$ & $1=$ & 9 & 10 & 13 & 12 & 14 & 11 & 15 \\
\hline $\begin{array}{c}\% \text { sign } \\
\text { prediction }\end{array}$ & 53.92 & - & 60.11 & 60.23 & 60.12 & 60.30 & 60.42 & 52.75 & 53.98 & 59.92 & 59.47 & 59.75 & 60.10 & 59.78 & 60.24 \\
\hline Rank & 13 & - & 6 & 4 & 5 & 2 & 1 & 14 & 12 & 8 & 11 & 10 & 7 & 9 & 3 \\
\hline \multicolumn{16}{|c|}{ Panel B: 2 Step Ahead } \\
\hline MSE & 6.06 & 6.07 & 6.08 & 6.07 & 6.08 & 6.08 & 6.07 & 6.08 & 6.08 & 7.20 & 7.73 & 7.38 & 7.93 & 7.19 & 8.59 \\
\hline Rank & 1 & $2=$ & $5=$ & $2=$ & $5=$ & $5=$ & $2=$ & $5=$ & $5=$ & 11 & 13 & 12 & 14 & 10 & 15 \\
\hline MAE & 5.38 & 5.38 & 5.40 & 5.39 & 5.40 & 5.40 & 5.39 & 5.42 & 5.40 & 6.05 & 6.33 & 6.14 & 6.41 & 6.07 & 6.67 \\
\hline Rank & $1=$ & $1=$ & $5=$ & $3=$ & $5=$ & $5=$ & $3=$ & 9 & $5=$ & 10 & 13 & 12 & 14 & 11 & 15 \\
\hline $\begin{array}{c}\% \text { sign } \\
\text { prediction }\end{array}$ & 54.00 & - & 52.72 & 53.87 & 53.38 & 53.98 & 55.40 & 51.96 & 53.46 & 51.99 & 52.64 & 52.19 & 52.19 & 51.72 & 52.82 \\
\hline Rank & 2 & - & 8 & 4 & 6 & 3 & 1 & 13 & 5 & 12 & 9 & $10=$ & $10=$ & 14 & 7 \\
\hline \multicolumn{16}{|c|}{ Panel C: 3 Step Ahead } \\
\hline MSE & 6.06 & 6.07 & 6.07 & 6.06 & 6.08 & 6.08 & 6.07 & 6.08 & 6.08 & 6.12 & 6.15 & 6.12 & 6.16 & 6.11 & 6.25 \\
\hline Rank & $1=$ & $3=$ & $3=$ & $1=$ & $6=$ & $6=$ & $3=$ & $6=$ & $6=$ & $11=$ & 13 & $1=$ & 14 & 10 & 15 \\
\hline MAE & 5.38 & 5.38 & 5.38 & 5.38 & 5.40 & 5.40 & 5.39 & 5.54 & 5.40 & 5.43 & 5.44 & 5.43 & 5.47 & 5.43 & 5.51 \\
\hline Rank & $1=$ & $1=$ & $1=$ & $1=$ & $6=$ & $6=$ & 5 & 15 & $6=$ & $9=$ & 12 & $9=$ & 13 & $9=$ & 14 \\
\hline $\begin{array}{c}\% \text { sign } \\
\text { prediction }\end{array}$ & 54.04 & - & 52.98 & 54.33 & 52.46 & 52.94 & 54.24 & 51.16 & 53.96 & 53.23 & 53.96 & 53.64 & 53.08 & 53.31 & 52.90 \\
\hline Rank & 3 & - & 9 & 1 & 13 & 11 & 2 & 14 & $4=$ & 8 & $4=$ & 6 & 9 & 7 & 12 \\
\hline
\end{tabular}

Table 5: Forecasting Performance for British Pound / German Mark

\begin{tabular}{|c|c|c|c|c|c|c|c|c|c|c|c|c|c|c|c|}
\hline & mean & r.w & 1 & $\begin{array}{c}\mathrm{R} \text { of ord } \\
3\end{array}$ & 10 & $\begin{array}{l}\text { AR- } \\
\text { AIC }\end{array}$ & $\begin{array}{l}\text { AR- } \\
\text { SIC }\end{array}$ & Bicorr. & $\begin{array}{c}\text { Exp. } \\
\text { Smooth }\end{array}$ & $\begin{array}{c}\text { CVAR } \\
\text { DEM_- } \\
\text { JPY }\end{array}$ & $\begin{array}{l}\text { CVAR } \\
\text { GBP_- }_{\text {USD }}\end{array}$ & $\begin{array}{l}\text { CVAR } \\
\mathrm{USD}_{-} \\
\mathrm{CHF}\end{array}$ & $\begin{array}{l}\text { CVAR } \\
\mathrm{USD}_{-} \\
\mathrm{DEM}\end{array}$ & $\begin{array}{l}\text { CVAR } \\
\text { USD_- }_{\text {ITL }}\end{array}$ & $\begin{array}{c}\text { CVAR } \\
\text { USD_- } \\
\text { JPY }\end{array}$ \\
\hline \multicolumn{16}{|c|}{ Panel A: 1 Step Ahead } \\
\hline MSE & 7.09 & 7.09 & 7.05 & 7.06 & 7.17 & 7.15 & 7.15 & 7.05 & 7.12 & 42.90 & 43.27 & 45.90 & 52.12 & 41.89 & 46.28 \\
\hline Rank & $4=$ & $4=$ & $1=$ & 3 & 9 & $7=$ & $7=$ & $1=$ & 6 & 11 & 12 & 13 & 15 & 10 & 14 \\
\hline MAE & 4.88 & 4.88 & 4.89 & 4.89 & 4.94 & 4.94 & 4.93 & 4.89 & 4.90 & 12.21 & 12.40 & 12.41 & 13.25 & 11.98 & 12.75 \\
\hline Rank & $1=$ & $1=$ & $3=$ & $3=$ & $8=$ & $8=$ & 7 & $3=$ & 6 & 11 & 12 & 13 & 15 & 10 & 14 \\
\hline $\begin{array}{c}\% \text { sign } \\
\text { prediction }\end{array}$ & 54.50 & - & 57.71 & 58.13 & 57.55 & 57.49 & 57.53 & 52.64 & 53.88 & 57.49 & 57.16 & 58.32 & 58.99 & 57.48 & 58.08 \\
\hline Rank & 12 & - & 5 & 3 & 6 & 8 & 7 & 14 & 13 & 9 & 11 & 2 & 1 & 10 & 4 \\
\hline \multicolumn{16}{|c|}{ Panel B: 2 Step Ahead } \\
\hline MSE & 7.09 & 7.09 & 7.10 & 7.07 & 7.20 & 7.18 & 7.17 & 9.54 & 7.12 & 8.42 & 8.54 & 9.10 & 9.39 & 8.53 & 8.67 \\
\hline Rank & $2=$ & $2=$ & 4 & 1 & 8 & 7 & 6 & 15 & 5 & 9 & 11 & 12 & 14 & 10 & 12 \\
\hline MAE & 4.88 & 4.88 & 4.90 & 4.89 & 4.93 & 4.93 & 4.92 & 4.96 & 4.91 & 5.54 & 5.62 & 5.78 & 5.91 & 5.59 & 5.67 \\
\hline Rank & $1=$ & $1=$ & 4 & 3 & $7=$ & $7=$ & 6 & 9 & 5 & 10 & 13 & 14 & 15 & 11 & 12 \\
\hline $\begin{array}{c}\% \text { sign } \\
\text { prediction }\end{array}$ & 54.52 & - & 53.27 & 54.03 & 52.94 & 52.97 & 53.32 & 52.04 & 53.25 & 52.56 & 53.19 & 52.52 & 52.48 & 52.74 & 52.16 \\
\hline Rank & 1 & - & 4 & 2 & 8 & 7 & 3 & 14 & 5 & 10 & 6 & 11 & 12 & 9 & 13 \\
\hline \multicolumn{16}{|c|}{ Panel C: 3 Step Ahead } \\
\hline MSE & 7.09 & 7.09 & 7.09 & 7.09 & 7.20 & 7.18 & 7.18 & 7.19 & 7.11 & 7.17 & 7.19 & 7.21 & 7.21 & 7.16 & 7.17 \\
\hline Rank & $1=$ & $1=$ & $1=$ & $1=$ & 13 & $9=$ & $9=$ & 11 & 5 & $7=$ & 12 & $14=$ & $14=$ & 6 & $7=$ \\
\hline MAE & 4.88 & 4.88 & 4.88 & 4.88 & 4.93 & 4.93 & 4.92 & 4.91 & 4.90 & 4.94 & 4.95 & 4.96 & 4.97 & 4.93 & 4.94 \\
\hline Rank & $1=$ & $1=$ & $1=$ & $1=$ & $8=$ & $8=$ & 7 & 6 & 5 & $11=$ & 13 & 14 & 15 & $8=$ & $11=$ \\
\hline $\begin{array}{c}\% \text { sign } \\
\text { prediction }\end{array}$ & 54.53 & - & 54.51 & 54.53 & 52.91 & 52.94 & 53.33 & 52.65 & 53.28 & 52.60 & 52.78 & 52.87 & 52.84 & 53.06 & 52.29 \\
\hline Rank & $1=$ & - & 3 & $1=$ & 8 & 7 & 4 & 12 & 5 & 13 & 11 & 9 & 10 & 6 & 14 \\
\hline
\end{tabular}


Table 6: Forecasting Performance for British Pound / US Dollar

\begin{tabular}{|c|c|c|c|c|c|c|c|c|c|c|c|c|c|c|c|}
\hline & mean & r.w & 1 & $\begin{array}{c}\mathrm{R} \text { of ord } \\
3\end{array}$ & r 10 & $\begin{array}{l}\text { AR- } \\
\text { AIC }\end{array}$ & $\begin{array}{l}\text { AR- } \\
\text { SIC }\end{array}$ & Bicorr & $\begin{array}{c}\text { Exp. } \\
\text { Smooth }\end{array}$ & $\begin{array}{c}\text { CVAR } \\
\text { DEM_ } \\
\text { JPY }\end{array}$ & $\begin{array}{l}\text { CVAR } \\
\mathrm{GBP}_{-} \\
\mathrm{DEM}^{-}\end{array}$ & $\begin{array}{l}\text { CVAR } \\
\mathrm{USD}_{-} \\
\mathrm{CHF}\end{array}$ & $\begin{array}{l}\text { CVAR } \\
\mathrm{USD}_{-} \\
\mathrm{DEM}\end{array}$ & $\begin{array}{c}\text { CVAR } \\
\text { USD_- }_{\text {ITL }}\end{array}$ & $\begin{array}{c}\text { CVAR } \\
\text { USD_ } \\
\text { JPY }\end{array}$ \\
\hline \multicolumn{16}{|c|}{ Panel A: 1 Step Ahead } \\
\hline MSE & 5.20 & 5.39 & 5.03 & 5.03 & 5.04 & 5.04 & 5.03 & 5.37 & 5.22 & 46.85 & 46.45 & 50.39 & 59.59 & 46.15 & 47.74 \\
\hline Rank & 6 & 9 & $1=$ & $1=$ & $4=$ & $4=$ & $1=$ & 8 & 7 & 11 & 12 & 14 & 15 & 10 & 13 \\
\hline MAE & 4.67 & 4.69 & 4.59 & 4.57 & 4.58 & 4.59 & 4.58 & 4.62 & 4.70 & 14.43 & 14.48 & 14.98 & 16.23 & 14.28 & 14.59 \\
\hline Rank & 7 & 8 & $4=$ & 1 & $2=$ & $4=$ & $2=$ & 6 & 9 & 11 & 12 & 14 & 15 & 10 & 13 \\
\hline $\begin{array}{c}\% \text { sign } \\
\text { prediction }\end{array}$ & 53.32 & - & 59.65 & 60.41 & 59.87 & 59.87 & 60.41 & 55.50 & 50.93 & 60.02 & 59.94 & 59.66 & 60.07 & 59.97 & 59.80 \\
\hline Rank & 13 & - & 11 & $1=$ & $7=$ & $7=$ & $1=$ & 12 & 14 & 3 & 6 & 10 & 4 & 5 & 9 \\
\hline \multicolumn{16}{|c|}{ Panel B: 2 Step Ahead } \\
\hline MSE & 5.20 & 5.39 & 5.21 & 5.39 & 5.21 & 5.22 & 5.20 & 5.24 & 5.22 & 6.70 & 6.94 & 7.26 & 8.28 & 6.76 & 6.61 \\
\hline Rank & $1=$ & $8=$ & $3=$ & $8=$ & $3=$ & $5=$ & $1=$ & 7 & $5=$ & 11 & 13 & 14 & 15 & 12 & 10 \\
\hline MAE & 4.67 & 4.69 & 4.68 & 4.69 & 4.68 & 4.68 & 4.68 & 4.72 & 4.69 & 5.58 & 5.68 & 5.85 & 6.27 & 5.61 & 5.54 \\
\hline Rank & 1 & $6=$ & $2=$ & $6=$ & $2=$ & $2=$ & $2=$ & 9 & $6=$ & 11 & 13 & 14 & 15 & 12 & 10 \\
\hline $\begin{array}{c}\% \text { sign } \\
\text { prediction }\end{array}$ & 53.33 & - & 51.63 & 52.62 & 52.98 & 52.84 & 52.81 & 52.20 & 52.16 & 50.54 & 50.58 & 50.74 & 51.99 & 50.84 & 50.74 \\
\hline Rank & 1 & - & 9 & 5 & 2 & 3 & 4 & 6 & 7 & 14 & 13 & $1=$ & 8 & 10 & $11=$ \\
\hline \multicolumn{16}{|c|}{ Panel C: 3 Step Ahead } \\
\hline MSE & 5.31 & 5.39 & 5.31 & 5.31 & 5.32 & 5.32 & 5.31 & 5.33 & 5.32 & 5.37 & 5.37 & 5.41 & 5.48 & 5.37 & 5.36 \\
\hline Rank & $1=$ & 13 & $1=$ & $1=$ & $5=$ & $5=$ & $1=$ & 8 & $5=$ & $10=$ & $10=$ & 14 & 15 & $10=$ & 9 \\
\hline MAE & 4.68 & 4.69 & 4.68 & 4.68 & 4.69 & 4.69 & 4.68 & 4.70 & 4.70 & 4.73 & 4.73 & 4.76 & 4.80 & 4.72 & 4.72 \\
\hline Rank & $1=$ & $5=$ & $1=$ & $1=$ & $5=$ & $5=$ & $1=$ & $8=$ & $8=$ & $12=$ & $12=$ & 14 & 15 & $10=$ & $10=$ \\
\hline $\begin{array}{c}\% \text { sign } \\
\text { prediction }\end{array}$ & 53.32 & - & 52.72 & 52.72 & 52.51 & 52.42 & 52.40 & 51.86 & 51.99 & 51.88 & 52.18 & 52.48 & 52.48 & 52.48 & 52.70 \\
\hline Rank & 1 & - & $2=$ & $2=$ & 5 & 9 & 10 & 14 & 12 & 13 & 11 & $6=$ & $6=$ & $6=$ & 4 \\
\hline
\end{tabular}

Table 7: Forecasting Performance for US Dollar / Swiss Franc

\begin{tabular}{|c|c|c|c|c|c|c|c|c|c|c|c|c|c|c|c|}
\hline & mean & r.w & 1 & $\begin{array}{c}\mathrm{R} \text { of ord } \\
3\end{array}$ & 10 & $\begin{array}{l}\text { AR- } \\
\text { AIC }\end{array}$ & $\begin{array}{l}\text { AR- } \\
\text { SIC }\end{array}$ & Bicorr. & $\begin{array}{c}\text { Exp. } \\
\text { Smooth }\end{array}$ & $\begin{array}{c}\text { CVAR } \\
\text { DEM_ } \\
\text { JPY }\end{array}$ & $\begin{array}{l}\text { CVAR } \\
\text { GBP } \\
\text { DEM }\end{array}$ & $\begin{array}{l}\text { CVAR } \\
\text { GBP_- } \\
\text { USD }\end{array}$ & $\begin{array}{l}\text { CVAR } \\
\text { USD_- } \\
\text { DEM }\end{array}$ & $\begin{array}{c}\text { CVAR } \\
\text { USD_- } \\
\text { ITL }\end{array}$ & $\begin{array}{c}\text { CVAR } \\
\text { USD_- } \\
\text { JPY }\end{array}$ \\
\hline \multicolumn{16}{|c|}{ Panel A: 1 Step Ahead } \\
\hline MSE & 10.63 & 10.63 & 10.28 & 10.28 & 10.28 & 10.28 & 10.28 & 10.28 & 10.65 & 47.24 & 54.09 & 57.62 & 119.69 & 47.33 & 51.77 \\
\hline Rank & $7=$ & $7=$ & $1=$ & $1=$ & $1=$ & $1=$ & $1=$ & $1=$ & 9 & 10 & 13 & 14 & 15 & 11 & 12 \\
\hline MAE & 6.25 & 6.25 & 6.19 & 6.18 & 6.20 & 6.20 & 6.19 & 6.19 & 6.28 & 13.93 & 14.60 & 15.81 & 22.06 & 13.91 & 14.72 \\
\hline Rank & $7=$ & $7=$ & $2=$ & 1 & $5=$ & $5=$ & $2=$ & $2=$ & 9 & 11 & 13 & 14 & 15 & 10 & 12 \\
\hline $\begin{array}{c}\% \text { sign } \\
\text { prediction }\end{array}$ & 53.08 & - & 59.48 & 58.83 & 58.32 & 58.37 & 58.43 & 53.45 & 52.42 & 59.25 & 58.95 & 57.76 & 58.99 & 59.26 & 58.77 \\
\hline Rank & 13 & - & 1 & 6 & 10 & 9 & 8 & 12 & 14 & 3 & 5 & 11 & 4 & 2 & 7 \\
\hline \multicolumn{16}{|c|}{ Panel B: 2 Step Ahead } \\
\hline MSE & 10.63 & 10.63 & 10.64 & 10.64 & 10.64 & 10.64 & 10.64 & 10.81 & 10.64 & 11.55 & 12.76 & 13.05 & 29.62 & 12.16 & 12.06 \\
\hline Rank & $1=$ & $1=$ & $3=$ & $3=$ & $3=$ & $3=$ & $3=$ & 9 & $3=$ & 10 & 13 & 14 & 15 & 12 & 11 \\
\hline MAE & 6.25 & 6.25 & 6.26 & 6.26 & 6.27 & 6.27 & 6.26 & 6.39 & 6.27 & 6.72 & 7.13 & 7.31 & 11.49 & 6.94 & 6.88 \\
\hline Rank & $1=$ & $1=$ & $3=$ & $3=$ & $6=$ & $6=$ & $3=$ & 9 & $6=$ & 10 & 13 & 14 & 15 & 12 & 11 \\
\hline $\begin{array}{c}\% \text { sign } \\
\text { prediction }\end{array}$ & 53.22 & - & 53.02 & 53.02 & 52.13 & 52.31 & 51.75 & 51.46 & 51.38 & 53.08 & 52.97 & 53.55 & 53.25 & 53.12 & 53.14 \\
\hline Rank & 3 & - & $7=$ & $7=$ & 11 & 10 & 12 & 13 & 14 & 6 & 9 & 1 & 2 & 5 & 4 \\
\hline \multicolumn{16}{|c|}{ Panel C: 3 Step Ahead } \\
\hline MSE & 10.63 & 10.63 & 10.63 & 10.64 & 10.64 & 10.64 & 10.64 & 10.68 & 10.65 & 10.69 & 10.73 & 10.78 & 12.83 & 10.83 & 10.68 \\
\hline Rank & $1=$ & $1=$ & $1=$ & $4=$ & $4=$ & $4=$ & $4=$ & $9=$ & 8 & 11 & 12 & 13 & 15 & 14 & $9=$ \\
\hline MAE & 6.25 & 6.25 & 6.25 & 6.25 & 6.27 & 6.27 & 6.26 & 6.27 & 6.27 & 6.28 & 6.32 & 6.34 & 7.22 & 6.38 & 6.30 \\
\hline Rank & $1=$ & $1=$ & $1=$ & $1=$ & $6=$ & $6=$ & 5 & $6=$ & $6=$ & 10 & 12 & 13 & 15 & 14 & 11 \\
\hline $\begin{array}{l}\% \text { sign } \\
\text { prediction } \\
\text { Rank }\end{array}$ & 53.16 & - & 53.06 & 53.11 & 52.62 & 52.84 & 52.73 & 51.86 & 51.97 & 52.54 & 53.36 & 52.59 & 52.68 & 51.29 & 52.16 \\
\hline
\end{tabular}


Table 8: Forecasting Performance for US Dollar / German Mark

\begin{tabular}{|c|c|c|c|c|c|c|c|c|c|c|c|c|c|c|c|}
\hline & mean & r.w & 1 & $\begin{array}{c}\mathrm{R} \text { of ord } \\
3\end{array}$ & r 10 & $\begin{array}{l}\text { AR- } \\
\text { AIC }\end{array}$ & $\begin{array}{l}\text { AR- } \\
\text { SIC }\end{array}$ & Bicorr. & $\begin{array}{c}\text { Exp. } \\
\text { Smooth }\end{array}$ & $\begin{array}{c}\text { CVAR } \\
\text { DEM_ } \\
\text { JPY }\end{array}$ & $\begin{array}{l}\text { CVAR } \\
\mathrm{GBP}_{-} \\
\mathrm{DEM}^{-}\end{array}$ & $\begin{array}{l}\text { CVAR } \\
\text { GBP_- } \\
\text { USD }\end{array}$ & $\begin{array}{l}\text { CVAR } \\
\text { USD_- } \\
\text { CHF }\end{array}$ & $\begin{array}{c}\text { CVAR } \\
\text { USD_- }_{\text {ITL }}\end{array}$ & $\begin{array}{c}\text { CVAR } \\
\text { USD_ } \\
\text { JPY }\end{array}$ \\
\hline \multicolumn{16}{|c|}{ Panel A: 1 Step Ahead } \\
\hline MSE & 4.62 & 4.71 & 4.60 & 4.60 & 4.62 & 4.62 & 4.60 & 4.69 & 4.64 & 16.15 & 15.53 & 17.13 & 19.40 & 15.31 & 15.52 \\
\hline Rank & $4=$ & 9 & $1=$ & $1=$ & $4=$ & $4=$ & $1=$ & 8 & 7 & 13 & 12 & 14 & 15 & 10 & 11 \\
\hline MAE & 4.46 & 4.47 & 4.43 & 4.43 & 4.44 & 4.44 & 4.43 & 4.44 & 4.49 & 8.57 & 8.28 & 8.76 & 9.34 & 8.22 & 8.28 \\
\hline Rank & 7 & 8 & $1=$ & $1=$ & $4=$ & $4=$ & $1=$ & $4=$ & 9 & 13 & $11=$ & 14 & 15 & 10 & $11=$ \\
\hline $\begin{array}{c}\% \text { sign } \\
\text { prediction }\end{array}$ & 51.90 & - & 57.14 & 57.11 & 55.78 & 56.46 & 57.20 & 51.19 & 51.30 & 57.51 & 57.53 & 57.04 & 57.67 & 57.45 & 57.18 \\
\hline Rank & 2 & - & 7 & 8 & 11 & 10 & 5 & 13 & 12 & 3 & 2 & 9 & 1 & 4 & 6 \\
\hline \multicolumn{16}{|c|}{ Panel B: 2 Step Ahead } \\
\hline MSE & 4.62 & 4.71 & 4.62 & 4.62 & 4.64 & 4.64 & 4.62 & 4.96 & 4.63 & 4.92 & 4.85 & 4.86 & 5.17 & 4.78 & 4.79 \\
\hline Rank & $1=$ & 8 & $1=$ & $1=$ & $6=$ & $6=$ & $1=$ & 14 & 5 & 13 & 11 & 12 & 15 & 9 & 10 \\
\hline MAE & 4.46 & 4.47 & 4.46 & 4.47 & 4.47 & 4.47 & 4.46 & 4.64 & 4.48 & 4.70 & 4.62 & 4.64 & 4.84 & 4.60 & 4.60 \\
\hline Rank & $1=$ & $4=$ & $1=$ & $4=$ & $4=$ & $4=$ & $1=$ & $12=$ & 8 & 14 & 11 & $12=$ & 15 & $9=$ & $9=$ \\
\hline $\begin{array}{c}\% \text { sign } \\
\text { prediction }\end{array}$ & 52.01 & - & 51.41 & 50.38 & 51.42 & 51.88 & 51.50 & 51.92 & 51.11 & 51.29 & 51.28 & 51.26 & 51.59 & 51.89 & 52.21 \\
\hline Rank & 2 & - & 9 & 14 & 8 & 5 & 7 & 3 & 13 & 10 & 11 & 12 & 6 & 4 & 1 \\
\hline \multicolumn{16}{|c|}{ Panel C: 3 Step Ahead } \\
\hline MSE & 4.62 & 4.71 & 4.62 & 4.62 & 4.64 & 4.64 & 4.62 & 4.68 & 4.64 & 4.65 & 4.64 & 4.64 & 4.68 & 4.64 & 4.64 \\
\hline Rank & $1=$ & 15 & $1=$ & $1=$ & $5=$ & $5=$ & $1=$ & $13=$ & $5=$ & $12=$ & $5=$ & $5=$ & $13=$ & $5=$ & $5=$ \\
\hline MAE & 4.46 & 4.47 & 4.46 & 4.46 & 4.47 & 4.47 & 4.46 & 4.49 & 4.48 & 4.48 & 4.47 & 4.48 & 4.52 & 4.47 & 4.47 \\
\hline Rank & $1=$ & $5=$ & $1=$ & $1=$ & $5=$ & $5=$ & $1=$ & 14 & $11=$ & $1=$ & $5=$ & $11=$ & 15 & $5=$ & $5=$ \\
\hline $\begin{array}{c}\% \text { sign } \\
\text { prediction }\end{array}$ & 52.05 & - & 52.26 & 52.67 & 51.36 & 51.45 & 52.34 & 52.05 & 51.77 & 52.34 & 52.41 & 51.80 & 52.57 & 52.65 & 51.55 \\
\hline Rank & $8=$ & - & 7 & 1 & 14 & 13 & $5=$ & $8=$ & 11 & $5=$ & 4 & 10 & 3 & 2 & 12 \\
\hline
\end{tabular}

Table 9: Forecasting Performance for US Dollar / Italian Lira

\begin{tabular}{|c|c|c|c|c|c|c|c|c|c|c|c|c|c|c|c|}
\hline & mean & r.w & 1 & $\begin{array}{c}\mathrm{R} \text { of ord } \\
3\end{array}$ & 10 & $\begin{array}{l}\text { AR- } \\
\text { AIC }\end{array}$ & $\begin{array}{l}\text { AR- } \\
\text { SIC }\end{array}$ & Bicorr. & $\begin{array}{c}\text { Exp. } \\
\text { Smooth }\end{array}$ & $\begin{array}{c}\text { CVAR } \\
\text { DEM_ } \\
\text { JPY }\end{array}$ & $\begin{array}{l}\text { CVAR } \\
\text { GBP }_{-} \\
\text {DEM }\end{array}$ & $\begin{array}{l}\text { CVAR } \\
\text { GBP_- } \\
\text { USD }\end{array}$ & $\begin{array}{l}\text { CVAR } \\
\mathrm{USD}_{-} \\
\mathrm{CHF}\end{array}$ & $\begin{array}{l}\text { CVAR } \\
\mathrm{USD}_{-} \\
\mathrm{DEM}^{-}\end{array}$ & $\begin{array}{c}\text { CVAR } \\
\text { USD_- } \\
\text { JPY }\end{array}$ \\
\hline \multicolumn{16}{|c|}{ Panel A: 1 Step Ahead } \\
\hline MSE & 9.29 & 9.43 & 8.16 & 7.99 & 7.99 & 7.99 & 7.99 & 8.09 & 9.36 & 106.91 & 104.32 & 112.05 & 111.47 & 112.33 & 110.58 \\
\hline Rank & 7 & 9 & 6 & $1=$ & $1=$ & $1=$ & $1=$ & 5 & 8 & 11 & 10 & 13 & 14 & 15 & 12 \\
\hline MAE & 5.77 & 5.79 & 5.65 & 5.61 & 5.60 & 5.60 & 5.60 & 5.62 & 5.80 & 20.38 & 20.11 & 21.06 & 20.51 & 19.96 & 20.62 \\
\hline Rank & 7 & 8 & 6 & 4 & $1=$ & $1=$ & $1=$ & 5 & 9 & 12 & 11 & 15 & 14 & 10 & 13 \\
\hline $\begin{array}{c}\% \text { sign } \\
\text { prediction }\end{array}$ & 51.96 & - & 59.79 & 61.28 & 61.17 & 61.26 & 61.15 & 56.94 & 48.33 & 59.92 & 60.14 & 60.19 & 60.40 & 60.13 & 60.26 \\
\hline Rank & 13 & - & 11 & 1 & 3 & 2 & 4 & 12 & 14 & 10 & 8 & 7 & 5 & 9 & 6 \\
\hline \multicolumn{16}{|c|}{ Panel B: 2 Step Ahead } \\
\hline MSE & 9.29 & 9.43 & 9.42 & 9.39 & 9.35 & 9.35 & 9.35 & 9.84 & 9.30 & 22.78 & 22.65 & 24.83 & 25.05 & 26.69 & 23.47 \\
\hline Rank & 1 & 8 & 7 & 6 & $3=$ & $3=$ & $3=$ & 9 & 2 & 11 & 10 & 13 & 14 & 15 & 12 \\
\hline MAE & 5.77 & 5.79 & 5.87 & 5.81 & 5.80 & 5.60 & 5.80 & 5.86 & 5.78 & 9.48 & 9.41 & 10.04 & 9.82 & 9.99 & 9.59 \\
\hline Rank & 2 & 4 & 9 & 7 & $5=$ & 1 & $5=$ & 8 & 3 & 11 & 10 & 15 & 13 & 14 & 12 \\
\hline $\begin{array}{c}\% \text { sign } \\
\text { prediction }\end{array}$ & 52.07 & - & 50.52 & 52.83 & 52.62 & 53.14 & 53.33 & 51.90 & 51.11 & 50.66 & 51.23 & 50.98 & 51.45 & 51.66 & 51.37 \\
\hline Rank & 5 & - & 14 & 3 & 4 & 2 & 1 & 6 & 11 & 13 & 10 & 12 & 9 & 7 & 8 \\
\hline \multicolumn{16}{|c|}{ Panel C: 3 Step Ahead } \\
\hline MSE & 9.29 & 9.43 & 9.33 & 9.32 & 9.33 & 9.33 & 9.34 & 9.58 & 9.30 & 11.06 & 11.10 & 11.55 & 11.54 & 12.03 & 11.20 \\
\hline Rank & 1 & 8 & $4=$ & 3 & $4=$ & $4=$ & 7 & 9 & 2 & 10 & 11 & 13 & 12 & 15 & 14 \\
\hline MAE & 5.77 & 5.79 & 5.79 & 5.80 & 5.80 & 5.80 & 5.80 & 5.82 & 5.78 & 6.46 & 6.47 & 6.67 & 6.60 & 6.72 & 6.51 \\
\hline Rank & 1 & $3=$ & $3=$ & $5=$ & $5=$ & $5=$ & $5=$ & 9 & 2 & 10 & 11 & 14 & 13 & 15 & 12 \\
\hline $\begin{array}{l}\% \text { sign } \\
\text { prediction }\end{array}$ & 51.97 & - & 52.16 & 51.30 & 52.46 & 52.75 & 53.00 & 51.95 & 51.03 & 52.19 & 51.77 & 52.38 & 52.24 & 52.21 & 51.85 \\
\hline Rank & 9 & - & 8 & 13 & 3 & 2 & 1 & 10 & 14 & 7 & 12 & 4 & 5 & 6 & 11 \\
\hline
\end{tabular}


Table 10: Forecasting Performance for US Dollar / Japanese Yen

\begin{tabular}{|c|c|c|c|c|c|c|c|c|c|c|c|c|c|c|c|}
\hline & mean & r.w & 1 & $\begin{array}{c}\mathrm{R} \text { of ord } \\
3\end{array}$ & r 10 & $\begin{array}{l}\text { AR- } \\
\text { AIC }\end{array}$ & $\begin{array}{l}\text { AR- } \\
\text { SIC }\end{array}$ & Bicorr. & $\begin{array}{c}\text { Exp. } \\
\text { Smooth }\end{array}$ & $\begin{array}{c}\text { CVAR } \\
\text { DEM_- } \\
\text { JPY }\end{array}$ & $\begin{array}{l}\text { CVAR } \\
\mathrm{GBP}_{-} \\
\mathrm{DEM}^{-}\end{array}$ & $\begin{array}{l}\text { CVAR } \\
\text { GBP_- } \\
\text { USD }\end{array}$ & $\begin{array}{l}\text { CVAR } \\
\mathrm{USD}_{-} \\
\mathrm{CHF}\end{array}$ & $\begin{array}{l}\text { CVAR } \\
\text { USD_ }_{-} \\
\text {DEM }\end{array}$ & $\begin{array}{c}\text { CVAR } \\
\text { USD_ } \\
\text { ITL }\end{array}$ \\
\hline \multicolumn{16}{|c|}{ Panel A: 1 Step Ahead } \\
\hline MSE & 6.32 & 6.33 & 6.14 & 6.36 & 6.14 & 7.41 & 7.41 & 6.14 & 6.14 & 24.52 & 23.64 & 24.53 & 25.63 & 30.93 & 23.74 \\
\hline Rank & 5 & 6 & $1=$ & 7 & $1=$ & $8=$ & $8=$ & $1=$ & $1=$ & 12 & 10 & 13 & 14 & 15 & 11 \\
\hline MAE & 5.43 & 5.43 & 5.36 & 5.46 & 5.35 & 6.04 & 6.04 & 5.35 & 5.35 & 10.92 & 10.70 & 10.90 & 11.13 & 12.26 & 10.73 \\
\hline Rank & $5=$ & $5=$ & 4 & 6 & $1=$ & $7=$ & $7=$ & $1=$ & $1=$ & 11 & 9 & 12 & 13 & 14 & 10 \\
\hline $\begin{array}{l}\% \text { sign } \\
\text { prediction }\end{array}$ & 53.30 & - & 58.67 & 52.12 & 58.59 & 52.18 & 51.99 & 53.64 & 58.84 & 58.96 & 58.50 & 58.63 & 58.84 & 58.76 & 58.63 \\
\hline Rank & 11 & - & 5 & 13 & 6 & 12 & 14 & 10 & $2=$ & 1 & 9 & $7=$ & $2=$ & 4 & $7=$ \\
\hline \multicolumn{16}{|c|}{ Panel B: 2 Step Ahead } \\
\hline MSE & 6.32 & 6.33 & 6.33 & 6.34 & 6.34 & 6.35 & 6.35 & 6.36 & 6.33 & 7.02 & 6.99 & 6.81 & 7.13 & 7.95 & 7.00 \\
\hline Rank & 1 & $2=$ & $2=$ & $5=$ & $5=$ & $7=$ & $7=$ & 9 & $2=$ & 13 & 11 & 10 & 14 & 15 & 12 \\
\hline MAE & 5.43 & 5.43 & 5.43 & 5.45 & 5.44 & 5.46 & 5.46 & 5.47 & 5.44 & 5.82 & 5.84 & 5.74 & 5.89 & 6.28 & 5.85 \\
\hline Rank & $1=$ & $1=$ & $1=$ & 6 & $4=$ & $7=$ & $7=$ & 9 & $4=$ & 11 & 12 & 10 & 14 & 15 & 13 \\
\hline $\begin{array}{l}\% \text { sign } \\
\text { prediction }\end{array}$ & 53.38 & - & 51.39 & 52.01 & 52.43 & 52.72 & 52.87 & 53.16 & 51.97 & 51.59 & 51.66 & 51.40 & 50.79 & 51.92 & 51.01 \\
\hline Rank & 1 & - & 12 & 6 & 5 & 4 & 3 & 2 & 7 & 10 & 9 & 11 & 14 & 8 & 13 \\
\hline \multicolumn{16}{|c|}{ Panel C: 3 Step Ahead } \\
\hline MSE & 6.33 & 6.33 & 6.33 & 6.36 & 6.35 & 6.36 & 6.36 & 6.37 & 6.34 & 6.34 & 6.35 & 6.35 & 6.37 & 6.40 & 6.36 \\
\hline Rank & $1=$ & $1=$ & $1=$ & $9=$ & $6=$ & $9=$ & $9=$ & $13=$ & $4=$ & $4=$ & $6=$ & $6=$ & $13=$ & 15 & $9=$ \\
\hline MAE & 5.43 & 5.43 & 5.43 & 5.46 & 5.44 & 5.46 & 5.46 & 5.46 & 5.44 & 5.46 & 5.46 & 5.46 & 5.46 & 5.48 & 5.46 \\
\hline Rank & $1=$ & $1=$ & $1=$ & $6=$ & $4=$ & $6=$ & $6=$ & $6=$ & $4=$ & $6=$ & $6=$ & $6=$ & $6=$ & 15 & $6=$ \\
\hline $\begin{array}{c}\% \text { sign } \\
\text { prediction }\end{array}$ & 53.36 & - & 52.97 & 52.57 & 52.83 & 53.05 & 53.16 & 52.87 & 52.61 & 51.94 & 52.67 & 51.83 & 53.06 & 52.82 & 53.08 \\
\hline Rank & 1 & - & 6 & 12 & 8 & 5 & 2 & 7 & 11 & 13 & 10 & 14 & 4 & 9 & 3 \\
\hline
\end{tabular}

